\title{
Chondrosarcoma: biology, genetics, and epigenetics [version
}

\section{1; peer review: 2 approved]}

\section{Warren A Chow}

Department of Medical Oncology \& Therapeutics Research, City of Hope, 1500 E. Duarte Rd, Duarte, CA, 91010, USA

V1 First published: 20 Nov 2018, 7(F1000 Faculty Rev):1826

https://doi.org/10.12688/f1000research.15953.1

Latest published: 20 Nov 2018, 7(F1000 Faculty Rev):1826

https://doi.org/10.12688/f1000research.15953.1

\section{Abstract}

Chondrosarcomas constitute a heterogeneous group of primary bone cancers characterized by hyaline cartilaginous neoplastic tissue. They are the second most common primary bone malignancy. The vast majority of chondrosarcomas are conventional chondrosarcomas, and most conventional chondrosarcomas are low- to intermediate-grade tumors (grade 1 or 2) which have indolent clinical behavior and low metastatic potential. Recurrence augurs a poor prognosis, as conventional chondrosarcomas are both radiation and chemotherapy resistant. Recent discoveries in the biology, genetics, and epigenetics of conventional chondrosarcomas have significantly advanced our understanding of the pathobiology of these tumors and offer insight into potential therapeutic targets.

\section{Keywords}

chondrosarcoma, genetics, epigenetics biology

\section{Open Peer Review}

Approval Status

1

2

version 1

20 Nov 2018

Faculty Reviews are review articles written by the prestigious Members of Faculty Opinions. The articles are commissioned and peer reviewed before publication to ensure that the final, published version is comprehensive and accessible. The reviewers who approved the final version are listed with their names and affiliations.

1. Robin L Jones, Sarcoma Unit, The Royal Marsden NHS Foundation Trust and Institute of Cancer Research, London, UK

2. Shreyaskumar Patel, The University of Texas MD Anderson Cancer Center, Houston, USA Any comments on the article can be found at the end of the article. 
Corresponding author: Warren A Chow (wchow@coh.org)

Author roles: Chow WA: Conceptualization, Data Curation, Formal Analysis, Investigation, Methodology, Project Administration, Resources, Supervision, Validation, Visualization, Writing - Original Draft Preparation, Writing - Review \& Editing

Competing interests: No competing interests were disclosed.

Grant information: The author(s) declared that no grants were involved in supporting this work.

Copyright: $\odot 2018$ Chow WA. This is an open access article distributed under the terms of the Creative Commons Attribution License, which permits unrestricted use, distribution, and reproduction in any medium, provided the original work is properly cited.

How to cite this article: Chow WA. Chondrosarcoma: biology, genetics, and epigenetics [version 1; peer review: 2 approved] F1000Research 2018, 7(F1000 Faculty Rev):1826 https://doi.org/10.12688/f1000research.15953.1

First published: 20 Nov 2018, 7(F1000 Faculty Rev):1826 https://doi.org/10.12688/f1000research.15953.1 


\section{Introduction}

Chondrosarcoma (CS) is the collective term for a group of heterogeneous, generally slow-growing, primary malignant tumors of bone characterized by the formation of hyaline cartilaginous neoplastic tissue. They primarily affect adults and are the second most common primary solid tumor of bone after osteogenic sarcoma ${ }^{1}$. CS account for approximately 3 new cases per $10^{6}$ population per year ${ }^{2}$. The prognosis for the majority of patients with CS is favorable and correlates with histologic grade and adequate surgical margins ${ }^{3}$. Development of pulmonary metastatic disease is typically an ominous sign, however, owing to chemotherapy and radiation resistance. This is a result of its underlying phenotype: poor vascularization, slow division rate, and hyaline cartilaginous matrix prohibiting access to the cells. Recent research on the biology, genetics, and epigenetics of CS will be reviewed.

More than $90 \%$ of $\mathrm{CS}$ are conventional $\mathrm{CS}^{3}$. Approximately $90 \%$ of these are low- to intermediate-grade (grade 1-2) and behave indolently and rarely metastasize ${ }^{3}$. Only $5-10 \%$ of conventional CS are grade 3 and have high metastatic potential ${ }^{4}$. CS that arise unassociated with a pre-existing lesion are called primary CS, and they are known as secondary if they develop from a pre-existing benign cartilage tumor such as an enchondroma or osteochondroma. They are further classified as central when they arise within the medullary cavity and peripheral when they arise from the bone surface, generally from the cartilage cap of an exostosis. Primary CS are nearly always central; secondary CS can be central or peripheral ${ }^{5}$. Although CS are considered both chemotherapy and radiation resistant, there are rare case reports of responses to conventional chemotherapeutic agents, including gemcitabine $e^{6,7}$.

Variant CS subtypes are significantly less common ${ }^{1,4,5}$. Dedifferentiated CS develop when low-grade conventional CS transform into a high-grade sarcoma, most frequently exhibiting features of osteosarcoma, fibrosarcoma, or undifferentiated pleomorphic sarcoma (UPS). Mesenchymal CS (MCS) is a highly malignant tumor exhibiting a bimorphic histologic pattern, with a highly undifferentiated small round cell component admixed with islands of well-differentiated cartilage. The HEY1-NCOA2 fusion has been identified in $\mathrm{MCS}^{8}$. Delayed recurrences after more than 20 years are not uncommon'. Clear cell CS is a lowgrade malignant tumor that most commonly involves the epiphyses of the long bones; the tumor cells are clear because their cytoplasm contains large amounts of glycogen ${ }^{10}$. Extraskeletal myxoid CS is also a slow-growing soft-tissue tumor containing prominent myxoid degeneration and characterized by a prolonged clinical course despite high rates of local recurrence and metastases ${ }^{11}$. It is characterized by $\mathrm{t}(9 ; 22)(\mathrm{q} 22 ; \mathrm{q} 12)$, fusing EWSR1 to NRA3 (genes formerly termed CHN, TEC, or $N O R 1)^{12}$. Other translocation partners to NRA3 include TAF15 and $T C F 12^{13,14}$. Because of the rarity of these variant CS, the remainder of this review will be dedicated to the more-prevalent conventional CS subtype.

\section{Normal bone formation}

Normal bone formation is a result of the production of hyaline cartilage matrix produced by chondrocytes, followed by ossification of the matrix by osteoblasts. First, mesenchymal stem cells differentiate at the epiphyseal growth plate into resting chondrocytes, which then migrate into a proliferative zone, where they multiply and increase the cellularity of the matrix (Figure 1). These proliferative cells then leave the epiphyseal plate before undergoing a hypertrophic phase, whereby they mature into large clear cells. Eventually, the cells undergo apoptosis, leaving behind the characteristic hypocellular hyaline cartilage matrix. Osteoblasts then migrate into this matrix and initiate ossification ${ }^{15}$.

\section{(Benign) cartilaginous neoplasms}

Osteochondromas are benign cartilaginous neoplasms consisting of a cartilage-capped bony projection on the surface of the bone, containing a marrow cavity continuous with the underlying bone ${ }^{16}$. They are one of the most common benign bone tumors. Approximately $15 \%$ of cases present with multiple lesions characteristic of the autosomal dominant multiple osteochondroma (MO) genetic disorder. The risk of malignant transformation to secondary peripheral CS is estimated at $1 \%$ for sporadic osteochondroma and less than $5 \%$ for $\mathrm{MO}^{17}$. Biallelic inactivation of the exostosin glycosyltransferase (EXT1 or EXT2) genes is observed in the majority of both sporadic and hereditary osteochondroma cases ${ }^{18,19}$. The EXT proteins are required for the polymerization of heparan sulfate (HS) chains forming the hyaline cartilage.

Interestingly, the cells of peripheral CS are predominantly EXT1 positive ${ }^{20}$, unlike the EXT1-negative cells within osteochondromas. Hence, EXT loss is likely an early event. The EXT-negative cells in osteochondroma create an extracellular mutation-promoting environment, whereupon neighboring EXTpositive cells acquire late-stage mutations that cause malignant transformation into CS.

Enchondromas are benign cartilaginous neoplasms that arise within the medullary cavity of bone, in contrast to osteochondromas, which arise on the surface. Histologically, they closely resemble grade $1 \mathrm{CS}$, and radiographic correlation for benign features is necessary for diagnosis. Mutations in the isocitrate dehydrogenase $(I D H) 1$ and 2 genes are present in $85 \%$ of hereditary enchondromatosis-associated disorders, Ollier disease (enchondromatosis only), and Maffuci syndrome (enchondromatosis and hemangiomas) and $50 \%$ of solitary enchondromas ${ }^{21}$. The risk of transformation into secondary central CS in patients affected by enchondromatosis is approximately $40 \%$ for Ollier disease and up to $53 \%$ in Maffuci syndrome ${ }^{22}$.

IDH mutations are present in 52-59\% of central CS and 57\% of dedifferentiated $\mathrm{CS}^{23}$. The presence of $I D H$ mutations in benign enchondromas and malignant CS supports the notion that $\mathrm{IDH}$ mutations are an early event, and these cartilaginous neoplasms represent a spectrum of malignant potential. IDH mutations are found in gliomas, acute myeloid leukemia (AML), and cholangiocarcinomas ${ }^{24}$. IDH is an enzyme involved in the tricarboxylic acid cycle (Krebs cycle), where it normally converts isocitrate to $\alpha$-ketoglutarate $(\alpha-\mathrm{KG})$. Mutant $I D H(\mathrm{~m} I D H)$ loses the ability to convert isocitrate to $\alpha-\mathrm{KG}$ and gains a new function that leads to the accumulation of $\delta$-2-hydroxyglutarate (D2HG). D2HG is considered an oncometabolite owing to its inhibition of $\alpha-\mathrm{KG}$-dependent dioxygenases involved in 

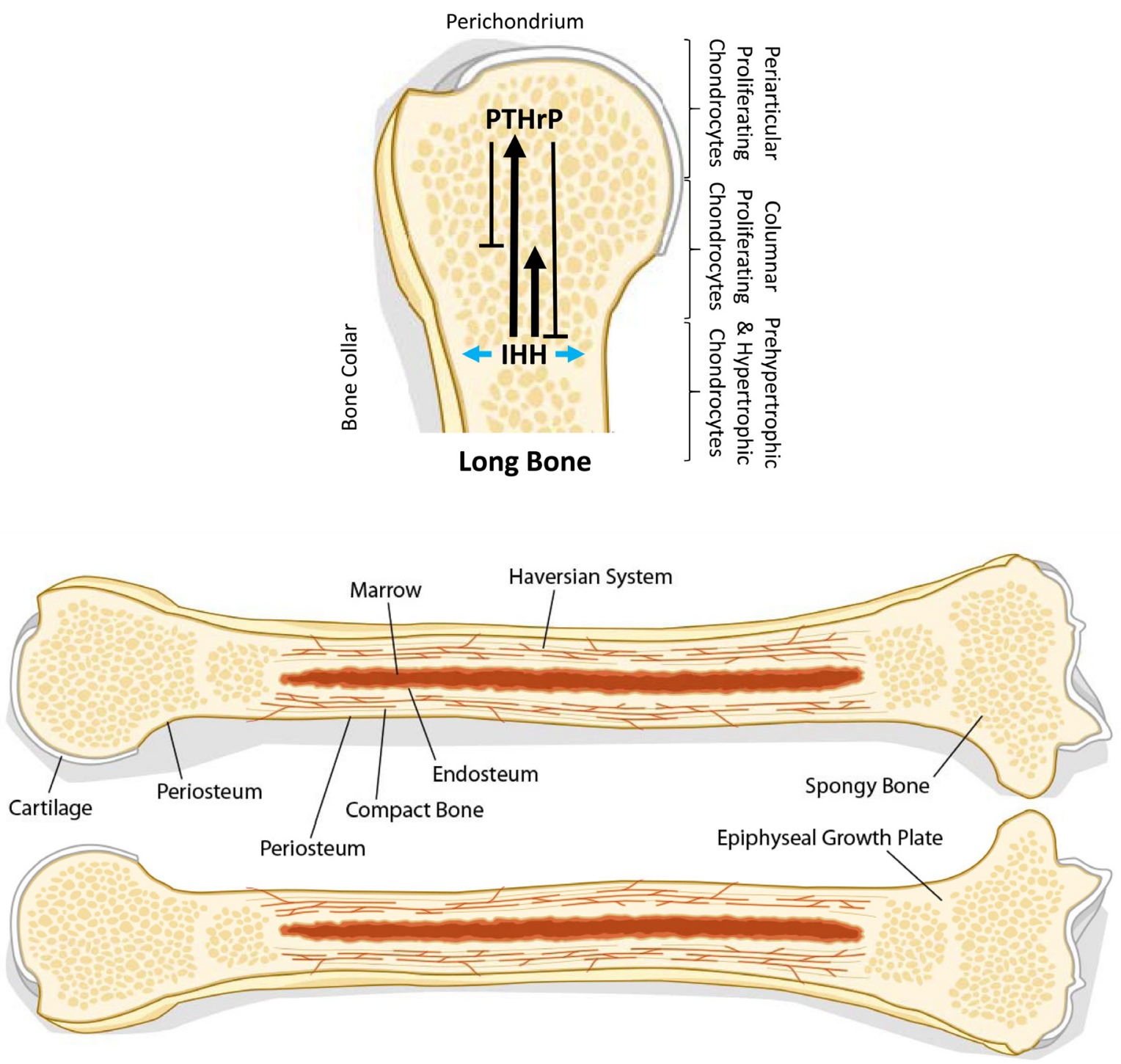

Figure 1. The IHH/PTHrP signaling pathway. Indian hedgehog $(\mathrm{IHH})$ is secreted by prehypertrophic and hypertrophic chondrocytes. $\mathrm{IHH}$ stimulates the secretion of parathyroid hormone-related protein (PTHrP) in the periarticular growth plate by periarticular proliferating chondrocytes (long solid arrow). IHH also induces the division of columnar proliferating chondrocytes in a positive feedback loop (short solid arrow). PTHrP then acts on the columnar proliferating chondrocytes to inhibit their hypertrophic differentiation and maintain them in a proliferative state (short solid T-bar). PTHrP also inhibits IHH secretion via a negative feedback loop, eventually shutting down the proliferative signal (long solid T-bar). IHH also acts on perichondrial cells to induce mature osteoblasts, which form a bone collar (blue arrows). Adapted from Chung UI, Schipani E, McMahon AP, Kronenberg HM. Indian hedgehog couples chondrogenesis to osteogenesis in endochondral bone development. J Clin Invest. 2001;107:295-304.

DNA and histone demethylation, which leads to a hypermethylated state of DNA and histones ${ }^{25}$. However, clearly IDH mutations alone are insufficient for malignant transformation similar to EXT loss.

Inhibition of oncogenic $\mathrm{m} I D H 1 / 2$ represents an opportunity for therapeutic intervention. Many of these inhibitors have been, or are being, evaluated in clinical trials for patients with AML or solid tumors, including $\mathrm{CS}^{26}$. Agios Pharmaceuticals have the furthest clinically developed compounds. Ivosidenib (AG-120), an IDH1 inhibitor, and enasidenib (AG-221), an IDH2 inhibitor, are FDA approved in the U.S. for refractory AML with $m I D H 1$ and $m I D H 2$, respectively. AG-881, a pan-mIDH1/2 inhibitor, is in early phase clinical testing. Likewise, IDH305 (Novartis), FT-2102 (Forma Therapeutics), and BAY1436032 (Bayer) are in early phase clinical testing. $\mathrm{m} I D H$ inhibition is a promising therapeutic approach in advanced CS.

\section{COL2A1}

The Cancer Genome Project (Wellcome Trust Sanger Institute, Cambridge, UK) performed the first large-scale whole-exome sequencing of 49 cases of 30 central, 4 peripheral, and 14 
dedifferentiated CS along with matching normal tissue ${ }^{27}$. In addition to confirming IDHI/2 mutations in $59 \%$ of the cases, the investigators identified hypermutability of the major cartilage collagen gene COL2A1, with insertions, deletions, and rearrangements identified in $37 \%$ of cases. COL $2 A 1$ encodes the $\alpha$-chain of type II collagen fibers, the major collagen constituent of articular cartilage. Disruption of the collagen maturation process through production of aberrant pro-collagen $\alpha$-chain is the likely result. The investigators hypothesized that COL2A1 mutations might bring about fundamental perturbation of matrix deposition and signaling that contributes to oncogenesis through abrogation of normal differentiation programs in CS.

\section{Hedgehog pathway}

The Hedgehog $(\mathrm{HH})$ pathway is vital for normal embryogenesis and plays essential roles in the maintenance, renewal, and regeneration of adult tissue. The mammalian $\mathrm{HH}$ ligand Indian (IHH) initiates signaling through binding to the canonical membrane receptor Patched (PTCH1). IHH binding to PTCH1 results in derepression of Smoothened (SMO) and results in SMO accumulation. SMO mediates activation of the GLI transcription factor to initiate a series of cellular responses that range from survival and proliferation to cell fate specification and differentiation ${ }^{28}$.

Chondrogenesis is regulated by the $\mathrm{IHH} /$ parathyroid hormonerelated protein (PTHrP) pathway. IHH, the product of proliferating chondrocytes, self-induces chondrocyte cell division as well as the secretion of PTHrP by perichondrial chondrocytes. PTHrP inhibits chondrocyte differentiation and maintains them in a proliferative state. PTHrP also negatively regulates IHH in a negative feedback loop to allow the chondrocytes to differentiate in a controlled manner (Figure 1).

Given the important role for $\mathrm{HH}$ signaling in chondrogenesis, therapeutic targeting of this pathway in CS has been investigated. The SMO inhibitors HPI-4 and IPI-926 have been reported to inhibit CS cell line growth in vitro and in vivo in a xenograft $\operatorname{model}^{29,30}$. Despite the promising preclinical reports, a randomized, double-blind, placebo-controlled phase 2 trial of IPI-926 (saridegib) in patients with advanced CS was negative ${ }^{31}$. Furthermore, a separate single-arm phase 2 trial of the SMO inhibitor vismodegib (GDC-0049) was similarly discouraging, as it did not meet the primary endpoint of 6-month clinical benefit ${ }^{32}$. Despite these disappointing results, new and morepotent $\mathrm{HH}$ pathway inhibitors are in development ${ }^{28}$.

\section{Tumor suppressor pathways}

Perturbations to tumor suppressor pathways are common in $\mathrm{CS}$. Alterations in the retinoblastoma $(\mathrm{Rb})$ tumor pathway were observed in $33 \%$ (whole-exome sequencing) to $96 \%$ (immunohistochemistry [IHC]) of cases of conventional and dedifferentiated $\mathrm{CS}^{27,33}$. $\mathrm{Rb}$ binds to and inhibits the E2F transcription factor to restrict $\mathrm{G} 1$ to $\mathrm{S}$ phase of the cell cycle division. This may occur through loss of heterozygosity $(\mathrm{LOH})$ of $\mathrm{Rb}$ in grade $3 \mathrm{CS}$ and dedifferentiated $\mathrm{CS}^{34}$, increased expression of cyclin-dependent kinase $4(\mathrm{CDK} 4)$ or cyclin D1, or reduced expression of $\mathrm{CDKN} 2 \mathrm{~A} / \mathrm{p} 16^{33}$. There are multiple CDK4/6 inhibitors (palbociclib, ribociclib, and abemaciclib) approved for the treatment of hormone receptor-positive breast cancer in combination with hormone therapy. CDK4/6 inhibitors are a rational approach to test in advanced CS.

TP53 is the most commonly mutated gene in human tumors. Likewise, alterations in the TP53 gene occur in 20-50\% of conventional and dedifferentiated $\mathrm{CS}^{27,35}$. p53 protein inactivation may also occur by binding to mouse double minute 2 homolog (MDM2). Overexpression of MDM2 by IHC was reported in $33 \%$ of high-grade CS, and MDM2 mRNA expression correlated with increasing histological grade ${ }^{33}$. These results suggest that strategies to block the p53-MDM2 interaction with small molecule antagonists like RG7112 (F Hoffman-La Roche) to restore p53 function may be a therapeutic avenue to explore in this subset of CS similar to its investigation in well-differentiated liposarcomas ${ }^{36}$.

\section{PI3K-Akt-mTOR pathway}

Membrane receptor tyrosine kinase (RTK) activation triggers activation of the lipid kinase PI3K, which generates PIP3. The serine-threonine kinase Akt is activated in part by binding of PIP3. Akt regulates multiple biological processes including cell survival, proliferation, growth, and glycogen metabolism. Phosphatase and tensin homolog (PTEN) is a lipid phosphatase that catalyzes the dephosphorylation of PIP3 to negatively regulate Akt. Loss of PTEN function has been implicated in many human cancers; however, PTEN mutations are rare in CS despite evidence of active Akt signaling ${ }^{37,38}$.

The mammalian target of rapamycin (mTOR) kinase regulates cell cycle progression, cellular proliferation and growth, autophagy, and angiogenesis by integrating energy and nutrient status and PI3K/AKT signaling ${ }^{39}$. S6 phosphorylation, a surrogate of $\mathrm{PI} 3 \mathrm{~K} / \mathrm{mTOR}$ activation, was observed in $73 / 106$ (69\%) of conventional and 11/25 (44\%) of dedifferentiated CS clinical samples ${ }^{38}$. Treatment with BEZ235, a dual PI3K/mTOR inhibitor, inhibited the growth of all CS cell lines tested and G1 arrest without induction of apoptosis ${ }^{38}$. A combination of the mTOR inhibitor sirolimus and low-dose daily cyclophosphamide in 10 patients with advanced conventional CS resulted in one (10\%) objective response, and six $(60 \%)$ patients had stabilization of disease for at least 6 months $^{40}$. Investigation of PI3K-Akt-mTOR pathway inhibition in CS should continue.

\section{microRNA}

MicroRNAs (miRNAs) are 18-24 nucleotide length, small noncoding RNAs that regulate eukaryotic gene expression at the post-transcriptional level by binding to $6-8$ nucleotides at the 3' untranslated region (3' UTR) of their target mRNAs. The short miRNA-mRNA binding site permits each miRNA to target multiple mRNAs. There are nearly 600 miRNAs in the human genome, which target approximately $60 \%$ of all human genes ${ }^{41,42}$.

miRNAs are involved in normal chondrogenesis. For example, miR-140 negatively regulates histone deacetylase 4 (HDAC4) in non-hypertrophic chondrocytes ${ }^{43}$. HDAC4 regulates the chondrocyte hypertrophic phase by inhibiting runt-related 
transcription factor 2 (RUNX2). When miR-140 binds HDAC4, RUNX2 inhibition is removed, and chondrocyte hypertrophy is enhanced prior to entering the apoptotic phase before ossification. Not surprisingly, miRNAs are also intimately involved in CS oncogenesis. miR-100 is a tumor suppressor that targets and inhibits mTOR and is downregulated in $\mathrm{CS}^{44}$. Forced expression of miR-100 sensitizes CS cell lines to cisplatin. Similarly, miR-30a decreases tumor proliferation, migration, and invasion through targeting of oncogenic SRY-related HMG box 4 $(\mathrm{SOX} 4)^{45}$. In contrast, miR-181a is considered a CS oncogene, as it is overexpressed in high-grade CS, is upregulated by hypoxia, and increases vascular endothelial growth factor (VEGF) expression by targeting regulator of G-protein signaling 16 (RGS16), a negative regulator of CXC chemokine receptor 4 (CXCR4) signaling ${ }^{46}$. These studies demonstrate the complex interplay of miRNA in CS oncogenesis.

\section{Epigenetics}

Post-transcriptional gene regulation is caused by DNA methylation and histone modification. In CS, the promoter of the tumor suppressor gene $P 16^{I N K 4 a}$ is hypermethylated ${ }^{47}$. Similarly, hypermethylation of the promoter region of the tumor suppressor RUNX3 transcription factor leads to reduced gene expression, increased proliferation, and reduced apoptosis in CS cells in vitro $^{48}$. Expression of RUNX3 correlates with improved CS clinical outcomes, further underlying the importance of DNA methylation in $\mathrm{CS}^{48}$. Naturally, the postulated mechanism is mutant $I D H$-induced accumulation of D2HG leading to inhibition of the demethylase TET methylcytosine dioxygenase proteins. However, a recent report suggests alternative mechanism(s) are responsible ${ }^{49}$. This analysis of 92 central and 45 peripheral CS tumors showed that although the CS were strongly positive for the $\mathrm{H} 3 \mathrm{~K} 4 \mathrm{me} 3, \mathrm{H} 3 \mathrm{~K} 9 \mathrm{me} 3$, and $\mathrm{H} 3 \mathrm{~K} 27 \mathrm{me} 3$ histone modifications, neither these modifications nor the variable levels of 5-hydroxymethylcytosine and 5-methylcytosine correlated with $I D H 1 / 2$ mutation status.

Inhibition of DNA methyltransferase in the H-EMC-SS CS cell line with decitabine restored expression of the hypermethylated gene encoding HS 3-O-sulfotransferase 2 (HS3ST2), an enzyme essential for HS biosynthesis ${ }^{50}$. This resulted in reduced proliferation, invasion, and adhesion. However, in the Swarm rat CS (SRC) model, global demethylation induced by decitabine led to CS progression in vitro and in vivo ${ }^{51}$. These conflicting results indicate significantly more research is needed before therapeutic targeting of epigenetic modification can proceed.

\section{Integrins}

Integrins are a family of heterodimeric transmembrane adhesion receptors which mediate cell-cell and cell-extracellular matrix (ECM) interactions. To date, 24 distinct integrin heterodimers have been identified, generated from various combinations of 18 $\alpha$ - and $8 \beta$-subunits. Integrin signaling interacts between both growth factor and chemokine signaling. As a result, integrins play critical roles in cancer cell migration, invasion, and metastasis through their two principal functions: attachment of the cell to the ECM and signal transduction from the ECM to the cell ${ }^{52}$.
CS consists of abundant ECM with few dividing cells and poor vascularity ${ }^{53}$. This may account for its primary resistance to both chemotherapy and radiation therapy. In CS, growth factors and chemokines/cytokines control the expression of specific integrins to promote cell migration. For example, insulin-like growth factor-1 (IGF-1) increases the migration of CS cells by increasing $\alpha v \beta 1$ integrin expression ${ }^{54}$, and CXCL12/SDF-1 chemokine, which is normally secreted by the lung epithelium, enhances the invasiveness of CS cells by increasing $\alpha v \beta 3$ integrin expression through the CXCR4/ERK/NF- $\mathrm{KB}$ pathway ${ }^{55}$. This may account for the tropism for lung metastases. Despite preclinical rationale for targeting integrin signaling, late-phase clinical trials of a synthetic peptide integrin antagonist (cilengitide) with radiotherapy in glioblastoma and an anti- $\alpha \mathrm{V}$-integrin antibody (abituzumab) in combination with chemotherapy and cetuximab (anti-EGFR antibody) in colorectal cancer have reported disappointing results ${ }^{56,57}$. These results highlight the complexity of targeting diverse integrin family members with significant redundancy.

\section{Angiogenesis}

Expression of the proangiogenic ligand VEGF is dependent upon hypoxia-inducible factor- $1 \alpha$ (HIF- $1 \alpha$ ), which is upregulated under hypoxic conditions ${ }^{58}$. Both normal and malignant chondrocytes induce HIF-1 $\alpha$ expression during hypoxia, and HIF- $1 \alpha$ expression directly correlates with reduced disease-free survival $^{59}$. Further, CS vascularity increases with increased histologic grade ${ }^{60}$. Accordingly, our phase 2 study of pazopanib, a multi-targeted receptor tyrosine kinase inhibitor (including VEGF-R) (NCT01330966), in patients with unresectable or metastatic CS has completed accrual and is currently undergoing analysis for safety and efficacy. Pending these results, inhibition of angiogenesis may be another therapeutic avenue for CS.

\section{Immunotherapy}

Immune checkpoint blockade with anti-PD1 (programmed death 1) and anti-PD-L1 (PD-ligand 1) antibodies has transformed solid tumor oncology. Positive clinical outcomes have generally correlated with tumor mutational burden (TMB) and PD-L1 expres$\operatorname{sion}^{61}$. In contrast, sarcomas generally have quiescent genomes and low TMB; CS were in the lowest decile in an analysis of TMB in over 100,000 cancer genomes in 167 distinct cancer types ${ }^{62}$. In addition, PD-L1 expression in sarcomas is $l \mathrm{low}^{63}$. In a phase 2 trial of the anti-PD-1 antibody pembrolizumab, conducted by the Sarcoma Alliance for Research through Collaboration (SARC), 1 out of $5(20 \%)$ subjects with dedifferentiated CS experienced RECIST response ${ }^{63}$. However, in a French multi-center, phase 2 trial of pembrolizumab with metronomic cyclophosphamide, 1 out of 50 patients with soft-tissue sarcoma (STS) experienced response, and 0 out of 2 subjects with extraskeletal CS responded ${ }^{64}$. Additionally, the Alliance for Clinical Trials in Oncology conducted a randomized phase 2 trial of the anti-PD-1 antibody nivolumab alone or in combination with the anti-CTLA4 antibody ipilimumab in patients with STS or bone sarcoma ${ }^{65}$. The overall response rate was 5\% with nivolumab monotherapy and $16 \%$ with the combination. However, bone sarcomas accounted for only $12 \%$ of the monotherapy cohort and $10 \%$ of the combination 
therapy cohort. Furthermore, only 1 dedifferentiated CS was in each cohort, and neither experienced response. Novel checkpoint blockade combinations will likely be required to advance immunotherapy in CS.

\section{Summary}

Advances in CS genetics, epigenetics, and biology have significantly informed this disease's underlying oncogenesis. However, this has yet to translate into substantial advancements in therapy. Sustained research will be needed in this rare and sometimes deadly cancer. Novel therapeutic breakthroughs will likely be a result in the not-too-distant future. It is probable that combination therapy targeting multiple pathways will be required to effectively treat advanced CS.

\section{Grant information}

The author(s) declared that no grants were involved in supporting this work.
1. Hogendoorn PCW, Bovée JV, Nielsen GP: Chondrosarcoma (grades I-III), including primary and secondary variants and periosteal chondrosarcoma. In Fletcher CD, Bridge JA, Hogendoorn PC, et al. editors. World Health Organization classification of tumours. Pathology and genetics of tumours of soft tissue and bone. $4^{\text {th }}$ edition. Lyon: IARC Press; 2013; 264-268.

2. van Oosterwijk JG, Anninga JK, Gelderblom $\mathrm{H}$, et al:: Update on targets and novel treatment options for high-grade osteosarcoma and chondrosarcoma. Hematol Oncol Clin North Am. 2013; 27(5): 1021-48.

PubMed Abstract | Publisher Full Text

3. Heck RK Jr, Peabody TD, Simon MA: Staging of primary malignancies of bone. CA Cancer J Clin. 2006; 56(6): 366-75.

PubMed Abstract | Publisher Full Text

4. Chow WA: Update on chondrosarcomas. Curr Opin Oncol. 2007; 19(4): 371-6. PubMed Abstract | Publisher Full Text

5. Shmookler B, Bickels J, Jelinek J, et al.: Bone and soft-tissue sarcomas: epidemiology, radiology, pathology and fundamentals of surgical treatment. In: Malawer M, Sugarbaker PH editors. Musculoskeletal cancer surgery: treatment of sarcomas and allied diseases. Boston: Kluwer Academic Publishers, 2001; 247-251.

Reference Source

6. Italiano A, Mir O, Cioffi A, et al:: Advanced chondrosarcomas: role of chemotherapy and survival. Ann Oncol. 2013; 24(11): 2916-22. PubMed Abstract | Publisher Full Text | Free Full Text

7. Provenzano S, Hindi N, Morosi C, et al.: Response of conventional chondrosarcoma to gemcitabine alone: a case report. Clin Sarcoma Res. 2015, 5: 9.

PubMed Abstract | Publisher Full Text | Free Full Text

8. Wang L, Motoi T, Khanin R, et al:: Identification of a novel, recurrent HEY1NCOA2 fusion in mesenchymal chondrosarcoma based on a genome-wide screen of exon-level expression data. Genes Chromosomes Cancer. 2012; 51(2): 127-39.

PubMed Abstract | Publisher Full Text | Free Full Text

9. Frezza AM, Cesari M, Baumhoer D, et al:: Mesenchymal chondrosarcoma: prognostic factors and outcome in $\mathbf{1 1 3}$ patients. A European Musculoskeletal Oncology Society study. Eur J Cancer. 2015; 51(3): 374-81.

PubMed Abstract | Publisher Full Text

10. McCarthy EF, Hogendoorn PCW: Clear cell chondrosarcoma. In: Fletcher CD, Bridge JA, Hogendoorn PC, et al. editors. World Health Organization classification of tumours. Pathology and genetics of tumours of soft tissue and bone. $4^{\text {th }}$ edition. Lyon: IARC Press; 2013; 273-274.

11. Drilon AD, Popat S, Bhuchar G, et al.: Extraskeletal myxoid chondrosarcoma: a retrospective review from 2 referral centers emphasizing long-term outcomes with surgery and chemotherapy. Cancer. 2008; 113(12): 3364-71. PubMed Abstract | Publisher Full Text | Free Full Text

12. Clark J, Benjamin H, Gill S, et al:: Fusion of the EWS gene to CHN, a member of the steroid/thyroid receptor gene superfamily, in a human myxoid chondrosarcoma. Oncogene. 1996; 12(2): 229-35. PubMed Abstract

13. Sjögren H, Meis-Kindblom J, Kindblom LG, et al.: Fusion of the EWS-related gene TAF2N to TEC in extraskeletal myxoid chondrosarcoma. Cancer Res. 1999; 59(20): 5064-7. PubMed Abstract

14. Hisaoka M, Ishida T, Imamura T, et al.: TFG is a novel fusion partner of NOR1 in extraskeletal myxoid chondrosarcoma. Genes Chromosomes Cancer. 2004; 40(4): 325-8.

PubMed Abstract | Publisher Full Text

15. Samuel AM, Costa J, Lindskog DM: Genetic alterations in chondrosarcomas - keys to targeted therapies? Cell Oncol (Dordr). 2014; 37(2): 95-105. PubMed Abstract | Publisher Full Text
16. Bovée JV, Heymann D, Wuyts W: Osteochondroma. In: Fletcher CD, Bridge JA, Hogendoorn PC, et al. editors. World Health Organization classification of tumours Pathology and genetics of tumours of soft tissue and bone. $4^{\text {th }}$ edition. Lyon: IARC Press; 2013; 250-251.

17. Wicklund $\mathrm{CL}$, Pauli RM, Johnston $\mathrm{D}$, et al.: Natural history study of hereditary multiple exostoses. Am J Med Genet. 1995; 55(1): 43-6. PubMled Abstract | Publisher Full Text

18. Ahn J, Lüdecke $\mathrm{HJ}$, Lindow $\mathrm{S}$, et al: Cloning of the putative tumour suppresso gene for hereditary multiple exostoses (EXT1). Nat Genet. 1995; 11(2): 137-43. PubMed Abstract | Publisher Full Text

19. Stickens D, Clines G, Burbee D, et al:: The EXT2 multiple exostoses gene defines a family of putative tumour suppressor genes. Nat Genet. 1996; 14(1): 25-32. PubMed Abstract | Publisher Full Text

20. de Andrea CE, Reijnders CM, Kroon HM, et al.: Secondary peripheral chondrosarcoma evolving from osteochondroma as a result of outgrowth of cells with functional EXT. Oncogene. 2012; 31(9): 1095-104. PubMed Abstract | Publisher Full Text

21. Amary MF, Damato S, Halai D, et al:: Ollier disease and Maffucci syndrome are caused by somatic mosaic mutations of IDH1 and IDH2. Nat Genet. 2011; 43(12): 1262-5.

PubMed Abstract | Publisher Full Text

22. Bovée JVMG, Alman BA: Endhondromatosis: Ollier disease and Maffucci syndrome. In: Fletcher CD, Bridge JA, Hogendoorn PCW, et al. editors. World Health Organization classification of tumours. Pathology and genetics of tumours of soft tissue and bone. $4^{\text {th }}$ edition. Lyon: IARC Press; 2013; 376-378.

23. Amary MF, Bacsi K, Maggiani F, et al:: IDH1 and IDH2 mutations are frequent events in central chondrosarcoma and central and periosteal chondromas but not in other mesenchymal tumours. J Pathol. 2011; 224(3): 334-43. PubMed Abstract | Publisher Full Text

24. Schaap FG, French PJ, Bovée JV: Mutations in the isocitrate dehydrogenase genes IDH1 and IDH2 in tumors. Adv Anat Pathol. 2013; 20(1): 32-8. PubMed Abstract | Publisher Full Text

25. F Dang L, White DW, Gross S, et al:: Cancer-associated IDH1 mutations produce 2-hydroxyglutarate. Nature. 2009; 462(7274): 739-44. PubMed Abstract | Publisher Full Text | Free Full Text | F1000 Recommendation

26. F Urban DJ, Martinez NJ, Davis MI, et al:: Assessing inhibitors of mutant isocitrate dehydrogenase using a suite of pre-clinical discovery assays. $\mathrm{Sci}$ Rep. 2017; 7(1): 12758

PubMed Abstract | Publisher Full Text | Free Full Text | F1000 Recommendation

27. F Tarpey PS, Behjati S, Cooke SL, et al:: Frequent mutation of the major cartilage collagen gene COL2A1 in chondrosarcoma. Nat Genet. 2013; 45(8): cartilage.

PubMed Abstract | Publisher Full Text | Free Full Text | F1000 Recommendation

28. F Wu F, Zhang Y, Sun B, et al:: Hedgehog Signaling: From Basic Biology to Cancer Therapy. Cell Chem Biol. 2017; 24(3): 252-80.

PubMed Abstract | Publisher Full Text | F1000 Recommendation

29. Xiang W, Jiang T, Guo F, et al.: Hedgehog pathway inhibitor-4 suppresses malignant properties of chondrosarcoma cells by disturbing tumor ciliogenesis. Oncol Rep. 2014; 32(4): 1622-30. PubMed Abstract | Publisher Full Text

30. Campbell VT, Nadesan P, Ali SA, et al:: Hedgehog pathway inhibition in chondrosarcoma using the smoothened inhibitor IPI-926 directly inhibits sarcoma cell growth. Mol Cancer Ther. 2014; 13(5): 1259-69. PubMed Abstract | Publisher Full Text

31. Wagner AJ, Hohenberger $P$, Okuno $S$, et al.: Results from a phase 2 randomized, placebo-controlled, double blind study of the hedgehog pathway antagonist IPI-926 in patients with advanced chondrosarcoma. New York, New York, USA 
Presented at the Connective Tissue Oncology Society Annual Meeting; 2013.

32. Italiano A, Le Cesne A, Bellera C, et al.: GDC-0449 in patients with advanced chondrosarcomas: a French Sarcoma Group/US and French National Cancer Institute Single-Arm Phase II Collaborative Study. Ann Oncol. 2013; 24(11): 2922-6.

PubMed Abstract | Publisher Full Text | Free Full Text

33. Schrage YM, Lam S, Jochemsen AG, et al: Central chondrosarcoma progression is associated with $\mathrm{pRb}$ pathway alterations: CDK4 downregulation and p16 overexpression inhibit cell growth in vitro. $J$ Cell Mol Med. 2009; 13(9A): 2843-52

PubMed Abstract | Publisher Full Text | Free Full Text

34. Röpke $\mathrm{M}$, Boltze $\mathrm{C}$, Meyer $\mathrm{B}$, et al:: Rb-loss is associated with high malignancy in chondrosarcoma. Oncol Rep. 2006; 15(1): 89-95.

PubMed Abstract | Publisher Full Text

35. Blasenbreu S, Baretton GB, Bender C, et al.: [TP53 gene aberrations in chondromatous neoplasms: correlation with immunohistochemical p53 accumulation and MDM2 expression]. Verh Dtsch Ges Pathol. 1998; 82: 284-9. PubMed Abstract

36. Ray-Coquard I, Blay JY, Italiano A, et al.: Effect of the MDM2 antagonist RG7112 on the P53 pathway in patients with MDM2-amplified, well-differentiated or dedifferentiated liposarcoma: an exploratory proof-of-mechanism study. Lancet Oncol. 2012; 13(11): 1133-40. PubMed Abstract | Publisher Full Text

37. Lin C, Meitner PA, Terek RM: PTEN mutation is rare in chondrosarcoma. Diagn Mol Pathol. 2002; 11(1): 22-6. PubMed Abstract | Publisher Full Text

38. Zhang YX, van Oosterwijk JG, Sicinska E, et al:: Functional profiling of receptor tyrosine kinases and downstream signaling in human chondrosarcomas identifies pathways for rational targeted therapy. Clin Cancer Res. 2013; 19(14): 3796-807.

PubMed Abstract | Publisher Full Text

39. Gibbons JJ, Abraham RT, Yu K: Mammalian target of rapamycin: discovery of rapamycin reveals a signaling pathway important for normal and cancer cell growth. Semin Oncol. 2009; 36 Suppl 3: S3-S17. PubMed Abstract | Publisher Full Tex

40. Bernstein-Molho R, Kollender Y, Issakov J, et al:: Clinical activity of mTOR inhibition in combination with cyclophosphamide in the treatment of recurrent unresectable chondrosarcomas. Cancer Chemother Pharmacol. 2012; 70(6): 855-60. PubMed Abstract | Publisher Full Text

41. Fromm B, Billipp T, Peck LE, et al:: A Uniform System for the Annotation of Vertebrate microRNA Genes and the Evolution of the Human microRNAome. Annu Rev Genet. 2015; 49: 213-42.

PubMed Abstract | Publisher Full Text | Free Full Text

42. Lewis BP, Burge CB, Bartel DP: Conserved seed pairing, often flanked by adenosines, indicates that thousands of human genes are microRNA targets. Cell. 2005; 120(1): 15-20.

PubMed Abstract | Publisher Full Text

43. F Martinez-Sanchez A, Dudek KA, Murphy CL: Regulation of human chondrocyte function through direct inhibition of cartilage master regulator SOX9 by microRNA-145 (miRNA-145). J Biol Chem. 2012; 287(2): 916-24. PubMed Abstract | Publisher Full Text | Free Full Text | F1000 Recommendation

44. Zhu Z, Wang CP, Zhang YF, et al.: MicroRNA-100 resensitizes resistant chondrosarcoma cells to cisplatin through direct targeting of mTOR. Asian Pac J Cancer Prev. 2014; 15(2): 917-23.

PubMed Abstract | Publisher Full Text

45. F Lu N, Lin T, Wang L, et al:: Association of SOX regulated by tumor suppressor miR-30a with poor prognosis in low-grade chondrosarcoma. Tumour Biol. 2015; 36(5): 3843-52.

PubMed Abstract | Publisher Full Text | F1000 Recommendation

46. F Sun X, Charbonneau C, Wei L, et al:: miR-181a Targets RGS16 to Promote Chondrosarcoma Growth, Angiogenesis, and Metastasis. Mol Cancer Res. 2015; 13(9): 1347-57.

PubMed Abstract | Publisher Full Text | Free Full Text | F1000 Recommendation

47. Asp J, Sangiorgi L, Inerot SE, et al.: Changes of the $\mathbf{p} 16$ gene but not the $\mathbf{p} 53$ gene in human chondrosarcoma tissues. Int J Cancer. 2000; 85(6): 782-6. PubMed Abstract | Publisher Full Text

48. Jin Z, Han YX, Han XR: Loss of RUNX3 expression may contribute to poor prognosis in patients with chondrosarcoma. J Mol Histol. 2013; 44(6): 645-52. PubMed Abstract | Publisher Full Text
49. F Cleven AHG, Suijker J, Agrogiannis G, et al: IDH1 or -2 mutations do not predict outcome and do not cause loss of 5-hydroxymethylcytosine or altered histone modifications in central chondrosarcomas. Clin Sarcoma Res. 2017; 7: 8. PubMed Abstract | Publisher Full Text | Free Full Text | F1000 Recommendation

50. Bui C, Ouzzine M, Talhaoui I, et al: Epigenetics: methylation-associated repression of heparan sulfate 3-O-sulfotransferase gene expression contributes to the invasive phenotype of H-EMC-SS chondrosarcoma cells. FASEB J. 2010; 24(2): 436-50. PubMed Abstract | Publisher Full Text

51. Hamm CA, Xie $\mathrm{H}$, Costa FF, et al: Global demethylation of rat chondrosarcoma cells after treatment with 5-aza-2'-deoxycytidine results in increased tumorigenicity. PLoS One. 2009; 4(12): e8340. PubMed Abstract | Publisher Full Text | Free Full Tex

52. F Hamidi $\mathrm{H}$, Pietilä M, Ivaska J: The complexity of integrins in cancer and new scopes for therapeutic targeting. Br J Cancer. 2016; 115(9): 1017-23. PubMed Abstract | Publisher Full Text | Free Full Text | F1000 Recommendation

53. Chen JC, Fong YC, Tang CH: Novel strategies for the treatment of chondrosarcomas: targeting integrins. Biomed Res Int. 2013; 2013: 396839. PubMed Abstract | Publisher Full Text | Free Full Text

54. Wu CM, Li TM, Hsu SF, et al:: IGF-I enhances $\alpha 5 \beta 1$ integrin expression and cell motility in human chondrosarcoma cells. J Cell Physiol. 2011; 226(12): 3270-7. PubMed Abstract | Publisher Full Text

55. Lai TH, Fong YC, Fu WM, et al:: Stromal cell-derived factor-1 increase alphavbeta3 integrin expression and invasion in human chondrosarcoma cells. J Cell Physiol. 2009; 218(2): 334-42. PubMed Abstract | Publisher Full Text

56. Stupp R, Hegi ME, Gorlia T, et al:: Cilengitide combined with standard treatment for patients with newly diagnosed glioblastoma with methylated MGMT promoter (CENTRIC EORTC 26071-22072 study): a multicentre, randomised, open-label, phase 3 trial. Lancet Oncol. 2014; 15(10): 1100-8. PubMed Abstract | Publisher Full Text

57. Élez E, Kocáková I, Höhler T, et al.: Abituzumab combined with cetuximab plus irinotecan versus cetuximab plus irinotecan alone for patients with KRAS wildtype metastatic colorectal cancer: the randomised phase I/II POSEIDON trial. Ann Oncol. 2015; 26(1): 132-40. PubMed Abstract | Publisher Full Text

58. Lin C, McGough R, Aswad B, et al:: Hypoxia induces HIF-1alpha and VEGF expression in chondrosarcoma cells and chondrocytes. J Orthop Res. 2004 22(6): 1175-81.

PubMed Abstract | Publisher Full Text

59. Kubo T, Sugita $T$, Shimose $S$, et al.: Expression of hypoxia-inducible factor1 alpha and its relationship to tumour angiogenesis and cell proliferation in cartilage tumours. J Bone Joint Surg Br. 2008; 90(3): 364-70. PubMed Abstract | Publisher Full Text

60. Ayala G, Liu C, Nicosia R, et al.: Microvasculature and VEGF expression in cartilaginous tumors. Hum Pathol. 2000; 31(3): 341-6. PubMed Abstract | Publisher Full Tex

61. F Carbone DP, Reck M, Paz-Ares L, et al.: First-Line Nivolumab in Stage IV or Recurrent Non-Small-Cell Lung Cancer. N Engl J Med. 2017; 376(25): 2415-26. PubMed Abstract | Publisher Full Text | F1000 Recommendation

62. F Chalmers ZR, Connelly CF, Fabrizio D, et al:: Analysis of 100,000 human cancer genomes reveals the landscape of tumor mutational burden. Genome Med. 2017; 9(1): 34

PubMed Abstract | Publisher Full Text | Free Full Text | F1000 Recommendation

63. F Tawbi HA, Burgess M, Bolejack V, et al.: Pembrolizumab in advanced softtissue sarcoma and bone sarcoma (SARC028): a multicentre, two-cohort, single-arm, open-label, phase 2 trial. Lancet Oncol. 2017; 18(11): 1493-501. PubMed Abstract | Publisher Full Text | F1000 Recommendation

64. F Toulmonde M, Penel N, Adam J, et al:: Use of PD-1 Targeting, Macrophage Infiltration, and IDO Pathway Activation in Sarcomas: A Phase 2 Clinical Trial. JAMA Oncol. 2018; 4(1): 93-7.

PubMed Abstract | Publisher Full Text | Free Full Text | F1000 Recommendation

65. F D'Angelo SP, Mahoney MR, van Tine BA, et al:: Nivolumab with or without ipilimumab treatment for metastatic sarcoma (Alliance A091401): two openlabel, non-comparative, randomised, phase 2 trials. Lancet Oncol. 2018; 19(3): 416-26.

PubMed Abstract | Publisher Full Text | Free Full Text | F1000 Recommendation 


\section{Open Peer Review}

\section{Current Peer Review Status:}

\section{Editorial Note on the Review Process}

Faculty Reviews are review articles written by the prestigious Members of Faculty Opinions. The articles are commissioned and peer reviewed before publication to ensure that the final, published version is comprehensive and accessible. The reviewers who approved the final version are listed with their names and affiliations.

\section{The reviewers who approved this article are:}

\section{Version 1}

\section{Shreyaskumar Patel}

Department of Sarcoma Medical Oncology, The University of Texas MD Anderson Cancer Center, Houston, Texas, USA

Competing Interests: No competing interests were disclosed.

\section{Robin L Jones}

Sarcoma Unit, The Royal Marsden NHS Foundation Trust and Institute of Cancer Research, London, UK Competing Interests: No competing interests were disclosed.

The benefits of publishing with F1000Research:

- Your article is published within days, with no editorial bias

- You can publish traditional articles, null/negative results, case reports, data notes and more

- The peer review process is transparent and collaborative

- Your article is indexed in PubMed after passing peer review

- Dedicated customer support at every stage

For pre-submission enquiries, contact research@f1000.com 